\title{
Soft Tissue Amyloid Neoplasm
}

National Cancer Institute

\section{Source}

National Cancer Institute. Soft Tissue Amyloid Neoplasm. NCI Thesaurus. Code C8323.

A soft tissue neoplasm composed of acellular amyloid material. 